\title{
The Concept of Property and Ownership in Islam
}

DOI: https://doi.org/10.47175/rissj.v2i4.314

\section{| Abdurrahman Siregar |}

Universitas Budi Darma

Medan, North Sumatra, Indonesia

*jonggi.siregar@gmail.com

\begin{abstract}
The aim of this research is to know how the concept of property ownership in Islamic economics according to Afzalur Rahman, to know how to implement the concept of property ownership in Islamic economics by Afzalur Rahman at this time and to know how Afzalur Rahman's thought analysis of concepts ownership of property in Islamic economics. The research method that writer use is library research (library research) where the data and data sources are obtained from a review of the literature according to the problem. The result showed that the opinion expressed by Afzalur Rahman on the concept of ownership in the Islamic economic system is in harmony with the economic principles that require the system an economy compatible with the Qur'an and Sunnah. Where Islam also wants every person in possession of good property in the form of goods or services obtained in a way halal both the form of substance and how to get it, not destroy and destroy human nature, nor do the persecution and exploitation, the purpose ultimately is to fight for the needs of human life and seek pleasure Hereafter is blessed by Allah SWT. KEYWORDS

Islamic economics; property ownership; Afzalur Rahman's thought analysis
\end{abstract}

\section{INTRODUCTION}

Peace can be achieved if the balance of life in society is achieved. To achieve a balance of life in society, regulations are needed that can reconcile individual interests with the interests of society.

Islamic economic activity is not solely material, but also aims to meet the needs of a person's life simply. To be greedy of wealth and attitudes related to mere material things, is very reproachful. Although in Islamic sharia it recognizes the existence of individual rights over an object, it does not mean that someone who owns it can do it arbitrarily. Because economic activity in the view of Islam, in addition to meeting the needs of life itself, is also still attached to the rights of others.

To meet the needs of human life as individual beings, God has given to God, various objects that can meet their needs. To meet these diverse needs, it is impossible to produce by the individual himself. In other words, he had to work with other people. Can be done, of course, must be supported by a peaceful atmosphere. Peace can be achieved if the balance of life in society is achieved. To achieve a balance of life in society, it is necessary for regulations to reconcile individual interests with the interests of society.

The economic change of Muslims, especially in Indonesia, must begin with the understanding that economic activity in the view of Islam is a demand for life with a worship dimension. This is stated in Q.S. Al-A'raf: 10 said that "Of course! we have built you on the earth and made it your livelihood; bit of it is that you say thank you.

It is also mentioned in (Surah Al-Mulk: 15, Q.S An-Naba ':11 and Q.S Jumu'ah: 10). Surah Al-Mulk: 15. Q.S An-Naba': 11 And We made a day to earn a living. Q.S Jumu'ah: 
10. Islamic economic activity is not solely material, but also aims to meet the needs of a person's life simply. To be greedy of wealth and attitudes related to mere material things, is very reproachful. Although in Islamic sharia it recognizes the existence of individual rights over an object, it does not mean that someone who owns it can do it arbitrarily. Because economic activity in the view of Islam, in addition to meeting the needs of life itself, is also still attached to the rights of others. The existence of other people's rights (community) to ownership rights obtained by a person is proven by the following provisions; prohibition of hoarding goods, prohibition of using property for things that harm society, such as producing goods that may not be owned and consumed according to Islamic views, for example: producing or selling books, tapes, films that are misleading and lead to distrust. , produce or sell prohibited food and beverages, such as prohibited food, liquor and other illegal drugs. The main principle in respecting property in the view of Islam is economic activity that does not conflict with aqidah, as stated in the Q.S. Hud: 84- 87.

They said: O Shu'aib! does your prayer instruct you that we should forsake what our ancestors worshiped or that we should not do what we please with regard to our possessions? So you are the forbidden, direct. Thus it can be stated that the Islamic economic system is an economic system that is applied in practice (economic application) in everyday life for individuals, families, community groups and government / rulers and the use of goods and services according to Islamic regulations. It is more broadly interpreted that the provisions of God that are obeyed are not only mechanical, but also in terms of ethics and morals. That is, in addition to fulfilling unlimited human satisfaction, economic activities aim to create the welfare of Muslims. Justice and balance implies that humans are free to carry out all economic activities, as long as there is no prohibition from God that regulates them. Responsibility means that humans as holders of God's mandate have responsibility for all choices and decisions. The Islamic economic system is different from other economic systems, as expressed by (Zadjuli in, Tadjoeddin 1992: 39 as quoted by Lubis, 2004: 15), namely: Basic assumptions / basic norms in the process and interaction of economic activities are enacted. In the Islamic Economic system which is the basic assumption is Islamic Shari'a, which is applied thoroughly both for individuals, families, community groups, rulers in meeting their needs. The principle of Islamic Economics is the application of the principles of efficiency and benefit with and preserving the environment. The motive of Islamic economics is to seek the good of the world and the hereafter. This is based on the provisions of Q.S. Al Baqarah: 208 said that O you who believe! put in the delivery of one and all and don't follow in Shaitan's footsteps; surely he is your open enemy About the Islamic commandment to be implemented in its entirety like it is stated in Q.S. Ar-Rum: 41 and Q.S. Al-Qasas: 77.

The issue of economic motives according to the Islamic view. The differences in the Islamic economic system with other economic systems above, are in line with the opinions of Ash-Syathibi 1941: 3-9 and al-Ghazali (Az-Zuhaili, 1986: 1020), as quoted (Burhan 2001: 120) Islamic economics Departing from the dimensions of philosophy and sharia values, while still using other economic measurement tools (Capra, 1999: 7-9) as quoted by Burhan, 2001: 120). Islamic economics is basically a combination of two types of science, namely economics and Islamic science (fiqh muamalat). Islamic economics also has two object activities, namely formal objects and material objects. The formal object in Islamic economics is the entire system of production and distribution of goods and services carried out by business actors both in terms of predicting profits losses that will be generated and from the legal aspect of a transaction. While the material object is all science related to Islamic economics, as quoted (Daulay, 2002: 99 from Anwar, 2002: 1). The difference between economics and muamalat fiqh is how to get it. Economics is obtained through 
observation (empiricism) of social phenomena of society in meeting their needs, for example, it can be seen from the theory of demand in economics: that if the demand for goods increases, the price of goods will automatically rise (Jones 1975; 15, as quoted by Daulay, 2002: 101). Fiqh muamalat is obtained through a direct search of the Qur'an and Hadith by means of qualitative fuqaha/reasoning. In terms of objectives, economics aims to assist people in meeting their needs, while fiqh muamalat functions to regulate contract law (aqad) both social and commercial (Ahmad, 1980: 59 as quoted by Daulay, 2002: 103). In short, it can be said that economics is more materialist-oriented, in other words, economics studies techniques and methods, while fiqh muamalat is more focused on things that are normative / determine legal status, whether or not business transactions (Hakim, 2002: 2 as quoted by Daulay, 2007). 2002: 103). There are two disciplines in the operation of Islamic which have differences in definition of the source of knowledge itself. Islamic economics is human thought, while the source of fiqh muamalat is revelation based on the guidance of the Qur'an and the Prophet's Hadith. This difference in the sources of science has led to the emergence of various assessments of human economic problems. For example, the economy will justify a liberal, capitalist and communist economic system, while muamalat fiqh still requires laws from the Qur'an and Hadith and cannot accept the three systems.

\section{RESEARCH METHODS}

The research method that writer use is library research where the data and data sources are obtained from a review of the literature according to the problem. In obtaining the data, the author uses secondary data. Secondary data include primary and secondary materials. Primary materials is Afzalur Rahman's work on the concept of property ownership in Islamic economics in Dotrin Islamic Economics Book, volume 1 and Muhammad WAS as Merchant. As for secondary material that is other related literature and in accordance with discussion of this study. While in the data collection the author uses the method analytical descriptive of collecting data, studying, reviewing various books and other written sources that are relevant to this study and are analyzed further. According Afzalur Rahman, the concept of property ownership in the Islamic economic system is the recognition of individual property rights and public property rights. Where the two rights are not is absolute.

\section{RESULTS AND DISCUSSION}

\section{The Concept of Wealth}

Assets as defined by 'ulama, are all things that are owned and owned by humans, can be stored and consumed when needed, both movable and immovable property (Dr. Zuhayli, al Fiqh al Islami, 4 / 41). Ibn Khaldun asserted: The point that cannot be told by anyone is that wealth is the staple food for humans both for food and drink, clothing and shelter. Strictly speaking, property can meet the demand for primary, secondary and complementary needs. Ibn Nujaim in his book al-Bahr, identifies that property is a name given to other than humans, created for the needs of human life, can be stored and utilized after human efforts and efforts both collectively and individually, so that they become valuable and legitimate to be used in accordance with sharia law.

1. Criteria for Assets. There are four criteria that can be taken from Ibn Nujaim's opinion, namely: First, something that will be considered a treasure if there is an element of effort and work done by humans on it, both individually and collectively. (Business and work elements) Second, something that has been considered a treasure will continue to have that nature as long as it has not been abandoned by everyone. If some people have left 
it because it cannot be used, but some are still able to use it, then it is still called a treasure. (Benefits and can be saved) Third, something that is considered a treasure must always coincide with a valuable trait that is considered legal and lawful by sharia. If there is something that is considered as property, but does not get a recommendation / contradicts from the sharia side, then the object is not called property. (Price Element) Fourth, property ownership is protected by sharia from all criminal acts because the property is glorified and respected. However, the honor and honor of the property is closely related to the provisions of sharia. (Honorable and Protected Sharia).

2. Property of Maqasid Sharia Perspective The scholars of Usul Fiqh describe that there are five maqasid (objectives) of sharia: a. Maintaining religious benefits, b. Soul, c. Intellect, d. Heredity (self-respect) and e. treasure. There are three maqasid treasures and treasures: First, circulation. Wealth (measured by money) is intended to always circulate and rotate in the production process and economic activity in order to always produce good results. In essence, money is only a medium of exchange that everyone has the same opportunity to own. So any act of hoarding wealth is forbidden in Islam, because it will slow down the speed of money which in turn will slow down economic growth. Fulfillment of zakat is one way to put money in the circulation of economic activity, so that Islam will fight against anyone who does not want to do it. To maintain the circulation and distribution of money properly, there are ways to do it: a) Islam forbids accumulating wealth by not issuing zakat. b) Prohibition of the practice of usury c) Prohibition of gambling (Maysir) d) Prohibition of hoarding (Ihtikar) e) Prohibition of property accumulated in a handful of people f) Rejected transactions (muamalah) Second, clean and clean (transparency). Ownership of property must be clear and clear from any issues that will cause a dispute to the owner. Therefore, sharia outlines the provisions that must be complied with in the transaction relationship, namely regarding:

a. Documents. Records must be made to ensure proper transactions. This is in accordance with QS Al Baqarah verse 282. In this surah, it is stated that when you want to carry out debt transactions in the long term, or muamalah, you should write an agreement and sanction and bring in witnesses.

b. Witness. It is also ordered in transactions, in case of future problems. In accordance with the Qur'an, the letter Al Baqarah verse 282 above.

c. Guarantee. These are items that are taken and stored from credit transactions to avoid the problem of default (renege). In accordance with QS. Al Baqarah verse 283 explains that This fair attitude also means that property ownership must be fair to: (a). relationship with Allah SWT, b. soul and self c. parents / family d. employees and workers e. Upholding the principles of advice and defending the truth and upholding the rule of law).

\section{Ownership}

Ownership in Islam is the bonding of a person with property rights authorized by Sharia. So that the ownership of each property is limited to acquisition and use by sharia. In the book Sharia Bank (Antonio Syafii, 1999), the Islamic view of wealth and economic activity is as follows:

1. The absolute owner of everything on earth, including property, is Allah SWT. Human ownership is only relative to doing trust and managing it according to its terms.

2. The status of human property is: 
a. Wealth is a trust from Creation, because human nature cannot hold wealth from anything.

b. This is a living adornment that allows humans to enjoy it well and not exaggerate (Q.S. Ali Imran 14; Al-Alaq: 6-7). In this Q.S. Ali Imran 14 can be include that Allah tests his servants through the abundance of wealth and worldly power. And also it is supported by Q.S.; Al-Alaq: 6-7.

c. Wealth as a test of faith (Q.S. Al-Anfal: 28) in this surah explains that Allah will test his servants through their children.

d. Wealth as worship, namely carrying out His orders and doing muamalah among fellow humans, especially zakat, infaq, and shadaqah activities such as Q.S Attaubah 41, ali Imran 133, Q.S. At-taubah 41: if you know Q.S. At-taubah 60 and Ali Imran 133.

3. Ownership of property can be done through, among others, proper business (a'mal) and livelihood (ma'isyah) and in accordance with the regulations such as in Q.S.almulk: 15; Al-Baqarah: 267; at-taubah: 105, Al-Jumu'ah: 4).

4. Allah gives the mercy to whom He wills, and Allah is Lord of mighty grace such explained in Q.S. At-Takatsur: 1-2, Al-Munafiqun: 9, al-Hasyir: 7, At-Takatsur: 1-2, Al-Munafiqun: 9, An-Nur: 37, and Al-Hasyir: 7.

5. It is forbidden to do forbidden business through usury activities (al-Baqarah: 273-281), gambling, buying and selling prohibited or prohibited item such as in Q.S. al-Maidah: 90-91 said that stealing, robbing, and spreading in Q.S. Al-maidah 38, cheating in size and scale in Q.S. Al-Muthafiffin: 1-6 in a wrong and dangerous way in Q.S. AlBaqarah, QS. Al-Baqarah: 273-281, QS. Al-Maidah: 90-91, QS. Al-Maidah 38, QS. Al-Muthafiffin: 1-6, Al Baqarah: 188. HR Imam Ahmad said that Sharia provisions governing personal wealth (Abdul Manan, 1970/1997):

a. Sustainable use; Islam does not allow unused wealth. Hadith: people who control land people no longer have the right to rule if 3 years does not work out well. So whoever works on people's land will not have the right to the land. The state (Islam) can revoke ownership if:

1. The owner is wasteful and unproductive.

2. Uses certain methods and ignores other means (investment).

3. Concentration of wealth is detrimental to society; this is done by the state in order to maintain balance and economic interests.

b. Zakat payment; This is done to reduce (and seek neglect) between the rich and the poor.

c. Infaq; useful use in the way of Allah

d. No harm to others.

e. Ownership is done legally (either obtaining or distributing it)

f. Balanced use (not wasteful and not stingy)

g. Utilization in accordance with the rights and designations. h. Utilization for the benefit of life (including with inheritance law)

\section{CONCLUSION AND RECOMMENDATION}

This economic system pluralism arises because of the inability of Muslims to create the concept of a sharia economic system that combines the economic system with sharia). This condition by Antonio describes: "On the one hand we are driving the wheels of economic development, but forget to bring the light of religion because we do not control the shari'ah, especially fiqh muamalat in depth. On the other hand, we find scientists and scholars who 
have deep knowledge of fiqh and other disciplines. Others, but do not have control and monitoring of economic phenomena and business chaos around them. The fundamental difference between the discipline of economics and fiqh muamalat requires thinking to synergize the two into one discipline. Apart from the problems above, Antonio (1992: 1), quoted (Lubis, 2004: 15), provides the most important offer in understanding Islamic economics, namely: Islamic economics wants to achieve a prosperous society in the world and the hereafter, personal property is relatively recognized as legitimate business and work and is used for legitimate things, it is forbidden to collect goods / property and make it abandoned, which belongs to the poor, to a certain extent property rights are. With zakat, trade is permitted, but usury is prohibited, there are no differences in ethnicity and lineage in cooperating and that the measure of the difference is the achievement of work. Hopefully we can practice this offer in our daily life.

\section{REFERENCES}

Agus, Bustanuddin. (2006). Islam dan Ekonomi : Suatu Tinjauan Sosiologi Agama. Padang: Andalas University Press.

Ahmad, Imam. Musnad Ahmad bin Hambāl. Beirut: Dār al-Fikr, t.t.

Antonio, Muhammad Syafi'i. (2012). Bank Syari'ah dari Teori ke Praktek. Jakarta: Gema Insani.

Asy'ari, M. (1992). Manusia Pembentuk Kebudayaan dalam Al-Qur'an. Yogyakarta: Lembaga Studi Filsafat Islam.

Bukhārī, Imām. Șahịh Bukhārī. Beirut: Dār al-Fikr, t.t.

Chapra, M. Umer. (2000). Sistem Moneter Islam. Jakarta: Gema Insani Press.

Chaudhry, Muhammad Sharif. (2012). Sistem Ekonomi Islam, Prinsip Dasar. Jakarta: Kencana Prenada Media Group.

Departemen Agama RI. (2002). Al-Qur'an dan Terjemahannya. Surabaya: al-Hidayah.

Departemen Pendidikan Nasional. (2005). Kamus Besar Bahasa Indonesia. Jakarta: Balai Pustaka.

Fauz Noor. (2012). Tapak Sabda (Sebuah Novel Filsafat). Yogyakarta: LKiS.

Ghazālī (al), Abū Hamīd. Ihya' 'Ulūm al-Dīn. Semarang: Thaha Putra, t.t.

Haritsi (al), Jaribah bin Ahmad. (2008). Fikih Ekonomi Umar bin al-Khattab. Jakarta: Khalifa.

Hidayat, Mohamad. (2010). An Introduction To The Sharia Economic: Pengantar Ekonomi Syari'ah. Jakarta: Zikrul Hakim.

Kaaf (al), Abdullah Zakiy. (2002). Ekonomi dalam Perspektif Islam (Bandung: CV Pustaka Setia.

Karim, Adiwarman Azwar. (2012). Ekonomi Mikro Islam. Jakarta: PT. Raja Grafindo Persada.

(2012).Sejarah Pemikiran Ekonomi Islam. Jakarta: PT. Raja Grafindo Persada.

Marthon. (2004). Said Sa'ad. Ekonomi Islam di Tengah Krisis Ekonomi Global. Jakarta: Zikrul Hakim.

Misri (al), Abdul Sami". (2006). Pilar-Pilar Ekonomi Islam. Yogyakarta: Pustaka Pelajar.

Law of the Republic of Indonesia Number 3 of 2006 concerning Amendments to Law No. 7 of 1989 concerning Religious Justice. 